\title{
Comparison of education and balneotherapy efficacy in patients with fibromyalgia syndrome: A randomized, controlled clinical study
}

\author{
Fibromiyalji sendromlu hastalarda eğitim ve balneoterapinin etkinliklerinin \\ karşılaştırılması: Randomize kontrollü klinik çalışma
}

\section{Burhan Fatih KOÇYiĞiT, Ali GÜR, Özlem ALTINDAĞ, Ahmet AKYOL, Savaş GÜRSOY}

\begin{abstract}
Summary
Objectives: Fibromyalgia is a disease characterized by chronic, widespread pain. Pharmacological and non-pharmacological treatment methods are used. The aim of the present study was to determine the effect of balneotherapy on treatment of fibromyalgia syndrome, compared with education alone.

Methods: A total of 66 patients diagnosed with fibromyalgia syndrome were randomly separated into balneotherapy and control groups. Patients in both groups were informed about fibromyalgia syndrome. In addition, the balneotherapy group received 21 sessions of spa treatment with $34.8^{\circ} \mathrm{C}$ thermomineral water, attending the spa 5 days a week. Patients were evaluated by visual analogue scale, tender point count, fibromyalgia impact questioning, and modified fatigue impact scale at initiation of treatment on the 15th day, 1st month, 3rd month, and 6th month. Evaluations were performed by the same doctor. Results: Statistically significant improvement was detected in all parameters, compared to starting evaluation, in both groups. Most improved results among all parameters were observed in the balneotherapy group on the first 3-month follow-up. In addition, all parameters beyond tender point count and modified fatigue impact were improved on 6-month follow-up.

Conclusion: It was concluded that addition of balneotherapy to patient education has both short- and long-term beneficial effects on female patients with fibromyalgia.
\end{abstract}

Keywords: Balneotherapy; fibromyalgia; patient education; pain.

\section{Özet}

Amaç: Fibromiyalji, kronik yaygın kas iskelet ağrısı ile karakterize bir hastalıktır. Tedavide farmakolojik ve non-farmakolojik yöntemler kullanıımaktadır. Bu çalışmayı planlarken amacımız, balneoterapinin FMS'de tedaviye katkısını eğitim ile karşılaştırarak belirlemekti.

Gereç ve Yöntem: Çalışmamızda, fibromiyalji sendromu tanısı almış olan 66 hasta randomize olarak ikiye ayrıldı, balneoterapi ve kontrol grubu olarak isimlendirildi. Her iki gruptaki hastaya fibromiyalji sendromu hakkında eğitim verildi. Balneoterapi grubundaki hastalara haftada 5 gün toplam 21 seans 34,8 derece termomineral su ile kaplıca tedavisi uygulandı. Hastalar aynı hekim tarafından tedavi başlangıcında, 15. gün, 1. ay, 3. ay ve 6. ayda görsel analog skala, hassas nokta sayısı, fibromiyalji etki sorgulaması, modifiye yorgunluk etki skalası ile değerlendirildi.

Bulgular: Her iki gruptaki hastalarda başlangıç değerlendirmelerine göre tüm parametrelerde istatistiksel olarak anlamlı derecede düzelme saptandı. Balneoterapi grubu, kontrol grubuna göre ilk 3 aylık takipte tüm parametrelerde üstündü. 6. aydaki takipte hassas nokta sayısı ve modifiye yorgunluk etki skalası dışındaki parametrelerde üstünlük devam etmekteydi.

Sonuç: Sonuç olarak hasta eğitimi ile balneoterapi tedavisinin birlikte kullanımının, 6 aylık takipte tek başına eğitime göre daha fazla klinik fayda sağladığı görüldü.

Anahtar sözcükler: Balneoterapi; fibromiyalji; hasta eğitimi; ağrı.

\section{Department of Physical Medicine and Rehabilitation, Gaziantep University Faculty of Medicine, Gaziantep, Turkey}

Submitted: 18.06.2015 Accepted after revision: 22.10.2015

Correspondence: Dr. Burhan Fatih Koçyiğit. Gaziantep Üniversitesi Tıp Fakültesi Hastanesi, Şahinbey, Gaziantep, Turkey

Tel: +90 - 342 - 3606060 e-mail: bfk2701@hotmail.com

() 2016 Turkish Society of Algology 


\section{Introduction}

Fibromyalgia syndrome (FMS) is a rheumatic disease characterized by chronic widespread pain. ${ }^{[1]}$ Morning stiffness, headache, irritable bowel and bladder syndrome, anxiety, depression, raynaud phenomenon, sleep disorders, and paresthesia accompany widespread body pain in the patients. FMS prevalence is calculated as $2 \%$. The prevalence is $3.4 \%$ in females and $0.5 \%$ in males. ${ }^{[2]}$

Since the etiopathogenesis of FMS has not been clarified yet, no standard treatment protocols are available. Pharmacological and non-pharmacological treatment methods are used in the treatment of the disease. Antidepressants and anti-epileptic medicines constitute the main pharmacological treatment. Exercise, patient education, heat applications and balneotherapy are common non-pharmacological treatment methods. ${ }^{[3]}$ Unable to take the adequate level of response from medical treatments, people were canalized to non-pharmacological treatment methods. Balneotherapy is a method used for many years in the treatment of rheumatic diseases. Our country has a rich potential of thermomineral water. Balneotherapy, is a very popular complementary therapy in our country used in the treatment of different kinds of diseases.

Our aim was to determine the effect of balneotherapy on FMS treatment by comparing with education.

\section{Materials and Methods}

Our study was planned as a randomized controlled follow-up study. 66 females between 18-55 years of age applying to Gaziantep University Faculty of Medicine Sahinbey Research and Application Hospital Physical Medicine and Rehabilitation Department polyclinic between February 2013 and January 2014 were included in the study. FMS diagnosis was made in accordance with 2010 ACR diagnosis criteria. Laboratory tests used for patients; complete blood count, erythrocyte sedimentation rate, $C$ reactive protein level, blood glucose level, hepatic and renal function tests, thyroid stimulant hormone level and X-rays. People who have a psychiatric disease story, immune deficiency, malign disease, diabetes mellitus, hypo/ hyperthyroid, chronic infection and inflammation, uncontrolled cardiac and renal disease, pregnant women, those in lactation period, those who had a spa treatment in the previous year and those who have used selective serotonin reuptake inhibitors, MAO inhibitors, selective serotonin noradrenaline reuptake inhibitors, pregabalin, gabapentin, non steroid antiinflammatory medicines and acetaminophen in the previous four weeks were not included in the study.

Before the study, Gaziantep University School of Medicine Medical Ethical Board consent was taken. Candidate participant pre informing was made and patient consents were taken.

66 patients were included in the study. Patients were randomly separated into two groups; the control group and balneotherapy group. Randomization was made by drawing lots. There were 33 patients both in the control group and balneotherapy group. 30 patients in the control group and 31 patients in the balneotherapy group completed the study. 1 patient due to an operation in the control group and two patients without presenting a reason were unable to complete the study. One patient in the balneotherapy group for the inability to accommodate to the spa treatment and another patient without presenting any reason couldn't complete the study.

\section{Patient Education}

Education on FMS was provided to the patients in both groups at the beginning of the treatment, 15th day, 1st month, 3rd month and 6th month. Education was provided to the patients in every control. Brief information such as what is FMS? What is the reason for FMS? How is FMS diagnosed? Does FMS get better? were given to the patients. It was emphasized that the disease is benign and doesn't cause tissue damage. It was stated that FMS is not a life threatening disease. It was told that conditions such as stress, depression, anxiety, sleep disorder, trauma, too much working could increase the complaints. Strategies for coping with the disease were told. It was emphasized that these strategies should be adapted to daily activities. During the education, the patient was imposed to believe in the fact that the necessary techniques can be learned in order to cope with the pain. Each education session lasted 20 minutes. Each session was given face-to-face with the patient by the same doctor in Gaziantep University Physical Medicine and Rehabilitation polyclinic. The education programme was constituted by our clinic. 


\section{Spa Treatment}

Spa treatment was applied to the patients in Uğurlu Thermal Plants operating within Gaziantep University Faculty of Medicine Hospital Physical Medicine and Rehabilitation Department. Spa treatment of all patients was organized between 09.00 and 11.00. Open cure treatment was given in daily visits. The temperature of mineral water was $34.8^{\circ} \mathrm{C}$. Thermomineral water content is shown in Table 1. Spa treatment was organized as a total of 21 sessions lasting 20 minutes five days a week in the form of entire body bath. All spa treatments were applied under the supervision of the doctor and physiotherapist in charge.

\section{Assessments}

The patients were evaluated 5 times with the mentioned scales at the beginning of the treatment, 15 th day, 1st month, 3rd month and 6th month. The evaluations were made by the same doctor in Gaziantep University Physical Medicine and Rehabilitation polyclinic. The patients joining the study didn't use any medicine that could change the evaluation results.

\section{Measurements}

Age, height, weight, body mass index (BMI), symptom duration, educational status, occupational sta- tus, marital status, tender point count (TPC) of all patients were recorded. Pain severity was evaluated visual analogue scale (VAS), disease severity by fibromyalgia impact questioning (FIQ), fatigue by modified fatigue impact scale (MFIS).

Tender points were determined by digital pressure from eighteen points indicated in the ACR classification criteria. ${ }^{[4]}$

VAS is used for the assessment of pain severity. The scale is $10 \mathrm{~cm}$ long and the patient marks the point $(0=$ no pain, $10=$ the most severe pain) on a vertical or horizontal line corresponding to severity of the pain felt.

FIQ measures 10 different factors namely physical function, feeling well, not being able to go to work, having challenges at work, fatigue, morning fatigue, stiffness, anxiety and depression. Higher scores indicated greater impairment. Total maximum score is $100 .{ }^{[5]}$

MFIS is evaluated by 21 questions. Each question is scored between 0-4 points. Total score is between $0-84$. The highest score gives the most severe fatigue value. ${ }^{[6]}$

Table 1. Mineral content of spa water

\begin{tabular}{lcc}
\hline Mineral & Concentration $(\mathbf{m g} / \mathbf{L})$ & Concentration $\mathbf{( m E q} / \mathbf{L})$ \\
\hline Sodium (Na) & 317.262 & 13.800 \\
Potassium (K) & 3.715 & 0.095 \\
Ammonium (NH) & 0.000 & 0.000 \\
Magnesium (Mg) & 12.763 & 1.050 \\
Calcium (Ca) & 125.801 & 6.290 \\
Manganese (Mn) & 0.000 & 0.000 \\
Iron (Fe) & 0.000 & 0.000 \\
Fluoride (F) & 1.130 & 0.060 \\
Chloride (Cl) & 534.586 & 15.080 \\
Bromur & 0.009 & 0.000 \\
lodide (I) & 0.008 & 0.000 \\
Nitride (NO2) & 0.425 & 0.009 \\
Nitrate (NO3) & 12.760 & 0.206 \\
Sulphate (SO4) & 27.000 & 0.563 \\
Bicarbonate (HCO3) & 305.000 & 5.000 \\
Sulphur (S) & 0.008 & 0.000 \\
Phosphate (HPO4) & 0.420 & 0.009 \\
Total & 1340.886 & 42.155 \\
\hline
\end{tabular}


Table 2. Sociodemographical findings of patients

\begin{tabular}{|c|c|c|c|c|}
\hline & & $\begin{array}{l}\text { Control } \\
(n=30)\end{array}$ & $\begin{array}{l}\text { Balneotherapy } \\
\quad(n=31)\end{array}$ & $\mathbf{p}$ \\
\hline & Gender & 30 Female & 31 Female & 1,000 \\
\hline & Age (years) (mean $\pm S S)$ & $41,77 \pm 10,51$ & $42.45 \pm 9.93$ & 0.795 \\
\hline & BMI (mean \pm SS) & $27.94 \pm 4.18$ & $27.65 \pm 5.00$ & 0.807 \\
\hline & Symptom duration (mean \pm SS) & $69,40 \pm 40,10$ & $73.65 \pm 59.15$ & 0.744 \\
\hline & Working at any job (n) & 6 & 7 & \\
\hline Marital & Married (n) & 23 & 26 & \\
\hline \multirow[t]{3}{*}{ Status } & Single, Widow or Separated (n) & 7 & 5 & 0.699 \\
\hline & Not Literate (n) & 6 & 0 & \\
\hline & Literate (n) & 1 & 2 & \\
\hline Education & Elementary school (n) & 14 & 16 & \\
\hline \multirow[t]{3}{*}{ Level } & Secondary school (n) & 1 & 2 & 0.142 \\
\hline & High school (n) & 4 & 8 & \\
\hline & University (n) & 4 & 3 & \\
\hline
\end{tabular}

\section{Statistical Analysis}

Statistical analyses of data were made with SPSS (Statistical Package for Social Sciences) for Windows version 11.0 package programme. Data distribution was evaluated with Shapiro-Wilk test. In the comparison of independent groups, in data with parametrical distribution Student-t and in data with nonparametrical distribution Mann Whitney $U$ tests were used. In the evaluation of repeating measurements in a group Friedman test was used. Significance limit was determined as $p<0.05$ statistically.

\section{Results}

Demographical characteristics of balneotherapy and control group were shown in Table 2. No statistically difference was detected among the sociodemographical data of both groups ( $p>0.05$ ).

Both groups were similar at the beginning of the study in terms of these variables ( $p>0.05)$. Findings are reported in Table 3.

When the control group was evaluated a statistically significant improvement was detected accord-

Table 3. Comparison of starting scores of the groups

\begin{tabular}{llccccc}
\hline & Group & Average & SD & Median & (min-max) & p \\
\hline \multirow{2}{*}{ VAS } & Control & 8,1 & 1,32 & 8,00 & $(5-10)$ & $0.754^{*}$ \\
& Balneotherapy & 8,06 & 1,23 & 8 & $(5-10)$ & \\
\multirow{2}{*}{ TPC } & Control & 12,5 & 3,28 & 13 & $(2-18)$ & $0.954^{*}$ \\
& Balneotherapy & 12,58 & 3,29 & 13 & $(4-18)$ & \\
\multirow{2}{*}{ FIQ } & Control & 69,88 & 8,5 & 69,89 & $(43,21-82,30)$ & $0.939^{1}$ \\
& Balneotherapy & 69,7 & 9,36 & 71,8 & $(44,75-82,43)$ & \\
\multirow{2}{*}{ MFIS } & Control & 56,6 & 7,48 & 58 & $(42-69)$ & $0.926^{1}$ \\
& Balneotherapy & 56,77 & 7,14 & 57 & $(46-70)$ & \\
\hline
\end{tabular}

'Student $t$ test; * Mann-Whitney U test; VAS: visual analogue scale, TPC: tender point count, FIQ: fibromyalgia impact scale, MFIS: modified fatigue impact scale. 


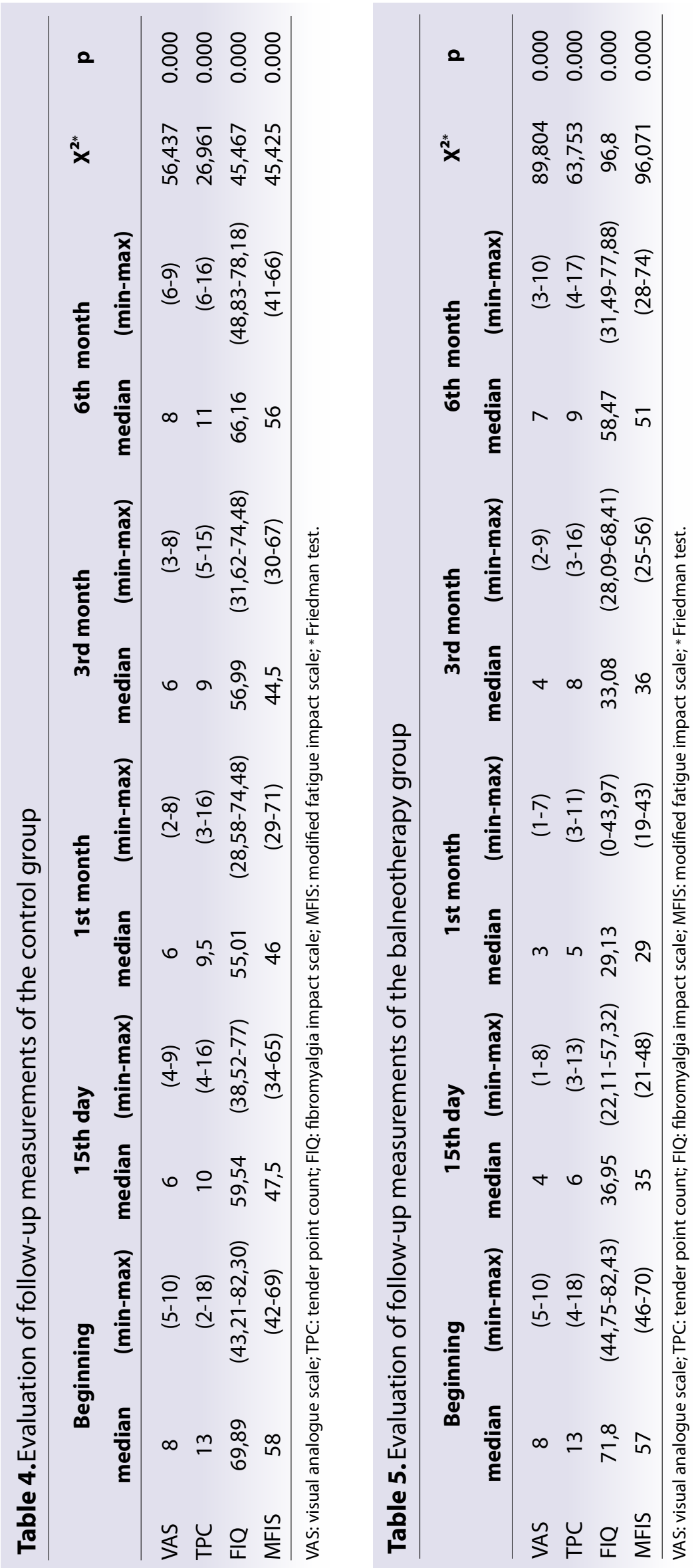

ing to the starting values in all follow-up parameters $(p<0.001)$. This significance continues for 6 months (Table 4).

When the balneotherapy group was evaluated a statistically significant improvement was detected according to the starting values in all follow-up parameters $(p<0.001)$. This significance continued for 6 months. Follow-up measurements of balneotherapy group are summarized in Table 5.

When the balneotherapy and control group were compared, balneotherapy group was superior to the control group in 15th day, 1st month and 3rd month evaluations $(p<0.01$ for 15 th day, 3rd month TPC, 3rd month VAS; $p<0.001$ for other parameters). Statistically significant difference was not detected between the groups in TPC, MFIS measurements in 6th month follow-ups ( $p>0.05$ ). Statistically significant difference in VAS, FIQ measurements in the sixth month continued in favour of balneotherapy group $(p<0.05)$. Findings are summarized in Table 6.

\section{Discussion}

Our study was planned as a randomized controlled follow-up study. Education was given to both groups at intervals. The patients in balneotherapy group had 21 sessions of spa treatment. Balneotherapy application provided a significant pain relief in patients with FMS in our study. During the 6 month follow-up, a significant improvement was detected in clinical parameters in both groups. Balneotherapy group was found better than the control group in all parameters in the first three month follow-up. Balneotherapy group continued to be better in the 6th month follow-up in parameters except TPC, MFIS.

In literature few studies evaluated the effectiveness of the education. The edu- 
Table 6. Comparison of follow-up parameters of balneotherapy and control groups

\begin{tabular}{|c|c|c|c|c|c|c|c|c|c|}
\hline & \multirow[t]{2}{*}{ Group } & \multicolumn{2}{|c|}{ 15th day } & \multicolumn{2}{|c|}{ 1st month } & \multicolumn{2}{|c|}{ 3rd month } & \multicolumn{2}{|c|}{ 6th month } \\
\hline & & & $\mathbf{p}$ & & $\mathbf{p}$ & & $\mathbf{p}$ & & $\mathbf{p}$ \\
\hline \multirow[t]{2}{*}{ VAS } & C & $6,00^{*}$ & 0,000 & $6,00^{*}$ & 0,000 & $6,00^{*}$ & 0,001 & $8,00^{*}$ & 0,011 \\
\hline & B & $4,00^{*}$ & & $3,00^{*}$ & & $4,00^{*}$ & & $7,00^{*}$ & \\
\hline \multirow[t]{2}{*}{ TPC } & C & $10,00^{*}$ & 0.001 & $9,50^{*}$ & 0,000 & $9,37 \pm 2,46^{1}$ & 0.003 & $11,23 \pm 2,37^{1}$ & 0.06 \\
\hline & B & $6,00^{*}$ & & $5,00^{*}$ & & $7,29 \pm 2,81^{1}$ & & $9,74 \pm 3,57^{1}$ & \\
\hline \multirow[t]{2}{*}{ FIQ } & C & $58,45 \pm 8,66^{1}$ & 0.000 & $55,01^{*}$ & 0,000 & $56,99 *$ & 0,000 & $65,76 \pm 6,24^{1}$ & 0.002 \\
\hline & B & $38,90 \pm 10,59^{1}$ & & $29,13^{*}$ & & $33,08^{*}$ & & $58,82 \pm 10,00^{1}$ & \\
\hline \multirow[t]{2}{*}{ MFIS } & C & $48,30 \pm 7,94^{1}$ & 0.000 & $46,90 \pm 9,59^{1}$ & 0.000 & $44,50^{*}$ & 0,000 & $54,93 \pm 6,46^{1}$ & 0.086 \\
\hline & B & $35,35 \pm 7,72^{1}$ & & $30,10 \pm 5,08^{1}$ & & $36,00^{*}$ & & $51,23 \pm 9,73^{1}$ & \\
\hline
\end{tabular}

VAS: visual analogue scale; TPC: tender point count; FIQ: fibromyalgia impact scale; MFIS: modified fatigue impact scale; C: Control group; B: Balneotherapy group; ${ }^{1}$ Student $t$ test $($ mean $\pm S D) ;{ }^{*}$ Mann-Whitney $\mathrm{U}$ test (median)

cation is generally used in combination with other treatment methods. Rooks et al. ${ }^{[7]}$ separated the patients in four main groups in the study with 207 patients. In the group given only education, a statistically significant improvement was detected in SF-36 physical role subscale, in self-efficacy scale. On the other hand in FIQ and Beck depression scale, a statistically significant improvement was not detected.

Bagdatli et al. ${ }^{[8]}$ performed a two-day education programme to the patients in a study they observed that the education was significantly effective in three-month follow-up period.

Patient education is a method recommended in FMS treatment guidelines. ${ }^{[3,9]}$ The necessity of informing about the natural course of the disease at the moment the diagnosis is made and the follow up is reported. ${ }^{[9]}$ Education sessions were performed at the beginning of the treatment and after the treatment at certain intervals to the patients in our study. The patients benefited significantly in all parameters in 6 month follow-up period. This situation can be associated to sparing time for the patients and communicating face to face during the follow-up in certain intervals, not only at the beginning of the education. Also health professionals experienced in FMS organizing educational sessions in accordance with the sociocultural level of the patients may be effective in the clinical advantage received.

There are different studies showing the efficiency of balneotherapy in FMS patients. Significant improvements were detected in VAS, FIQ, TPC and Beck depression scale in randomized controlled studies. [10,11,12] The results of meta-analysis and systematic reviews also reveal the efficiency of balneotherapy in FMS. ${ }^{[13,14]}$

Our results were also in line with the literature. In three month follow-up in all parameters and in the parameters except TPC, MFIS in 6th month followups balneotherapy group was found better than the control group.

Efficiency of balneotherapy is explained by different mechanisms. Weight is decreased by the lifting force in the water and relaxation in muscles and analgesia are provided by stimulating the contact receptors. Beta endorphin and cortisol level increases with the heat. ${ }^{[15,16]}$ Pain threshold increases by gate control theory in patients. It has been determined that balneotherapy decreases interleukin 1, prostaglandin E2 and leukotriene B4 levels in FMS patients. ${ }^{[12]}$

Some limitations are present in our study. First of all the patient groups are small. The study was not blind planned. Another limitation is that the patients in balneotherapy group going to the spa centre cause an environmental change. Patients leaving their routine daily life and being in a different environment may cause a decrease in disease activity. Interaction and socializing of patients in spa centre may create a positive effect. For this reason the well-being of pa- 
tients in balneotherapy group cannot be totally explained by thermomineral water effect.

As a result balneotherapy is an effective treatment method in FMS patients. Adding informative educational sessions to the treatment increases the efficiency of the treatment. We think that balneotherapy and patient education is a more effective and trustable treatment alternative in FMS about which a clear consensus on the treatment is not available yet. Larger patient groups and longer observation periods are warranted to determine the reproducibility of our results.

\section{Conflict-of-interest issues regarding the authorship or article: None declared.}

\section{Peer-rewiew: Externally peer-reviewed.}

\section{References}

1. Bigatti SM, Hernandez AM, Cronan TA, Rand KL. Sleep disturbances in fibromyalgia syndrome: relationship to pain and depression. Arthritis Rheum 2008;59(7):961-7. CrossRef

2. Wolfe F, Ross K, Anderson J, Russell IJ, Hebert L. The prevalence and characteristics of fibromyalgia in the general population. Arthritis Rheum 1995;38(1):19-28. CrossRef

3. Carville SF, Arendt-Nielsen L, Bliddal H, Blotman F, Branco $J C$, Buskila D, et al. EULAR evidence-based recommendations for the management of fibromyalgia syndrome. Ann Rheum Dis 2008;67(4):536-41. CrossRef

4. Wolfe F, Smythe HA, Yunus MB, Bennett RM, Bombardier C, Goldenberg DL, et al. The American College of Rheumatology 1990 Criteria for the Classification of Fibromyalgia. Report of the Multicenter Criteria Committee. Arthritis Rheum 1990;33(2):160-72. CrossRef

5. Sarmer S, Ergin S, Yavuzer G. The validity and reliability of the Turkish version of the Fibromyalgia Impact Questionnaire. Rheumatol Int 2000;20(1):9-12. CrossRef

6. Noonan VK, Cook KF, Bamer AM, Choi SW, Kim J, Amtmann D. Measuring fatigue in persons with multiple sclerosis: creating a crosswalk between the Modified Fatigue Impact Scale and the PROMIS Fatigue Short Form. Qual Life Res 2012;21(7):1123-33. CrossRef

7. Rooks DS, Gautam S, Romeling M, Cross ML, Stratigakis D, Evans B, et al. Group exercise, education, and combination self-management in women with fibromyalgia: a randomized trial. Arch Intern Med 2007;167(20):2192-200. CrossRef

8. Bağdatlı AO, Donmez A, Eröksüz R, Bahadır G, Turan M, Erdoğan N. Does addition of 'mud-pack and hot pool treatment' to patient education make a difference in fibromyalgia patients? A randomized controlled single blind study. Int J Biometeorol 2015;59(12):1905-11. CrossRef

9. Fitzcharles MA, Shir Y, Ablin JN, Buskila D, Amital H, Henningsen $P$, et al. Classification and clinical diagnosis of fibromyalgia syndrome: recommendations of recent evidence-based interdisciplinary guidelines. Evid Based Complement Alternat Med 2013;2013:528952. CrossRef

10. Evcik D, Kizilay B, Gökçen E. The effects of balneotherapy on fibromyalgia patients. Rheumatol Int 2002;22(2):56-9.

11. Dönmez $A$, Karagülle $M Z$, Tercan $N$, Dinler $M$, Işsever $H$, Karagülle $M$, et al. SPA therapy in fibromyalgia: a randomised controlled clinic study. Rheumatol Int 2005;26(2):168-72. CrossRef

12. Ardiç F, Ozgen M, Aybek H, Rota S, Cubukçu D, Gökgöz A. Effects of balneotherapy on serum IL-1, PGE2 and LTB4 levels in fibromyalgia patients. Rheumatol Int 2007;27(5):4416. CrossRef

13. Falagas ME, Zarkadoulia E, Rafailidis PI. The therapeutic effect of balneotherapy: evaluation of the evidence from randomised controlled trials. Int J Clin Pract 2009;63(7):106884. CrossRef

14. McVeigh JG, McGaughey $H$, Hall M, Kane P. The effectiveness of hydrotherapy in the management of fibromyalgia syndrome: a systematic review. Rheumatol Int 2008;29(2):119-30. CrossRef

15. Bellometti S, Galzigna L. Function of the hypothalamic adrenal axis in patients with fibromyalgia syndrome undergoing mud-pack treatment. Int J Clin Pharmacol Res 1999;19(1):27-33.

16. Odabasi E, Turan M, Erdem H, Tekbas F. Does mud pack treatment have any chemical effect? A randomized controlled clinical study. J Altern Complement Med 2008;14(5):559-65. CrossRef 